\title{
The Xbox/Kinect use in poststroke rehabilitation settings: a systematic review
}

\author{
A utilização do Xbox/Kinect na reabilitação pós-acidente vascular cerebral: uma revisão sistemática \\ Túlio Brandão XAVIER-ROCHA 1,2, Lara CARNEIRO ${ }^{3,4,5}$, Gustavo Celestino MARTINS6, \\ Guanis de Barros VILELA-JÚNIOR ${ }^{6}$, Ricardo Pablo PASSOS ${ }^{6}$, Camila Castelo Branco PUPE?, \\ Osvaldo José Moreira do NASCIMENTO', Desirée Sant'Ana HAIKAL7?, Renato Sobral MONTEIRO-JUNIOR ${ }^{1,7}$
}

\begin{abstract}
Background: Active games based on virtual reality have been widely used in the rehabilitation of many clinical conditions. However, studies on the use of Xbox/Kinect are rare, and technology application in stroke treatment is not clear yet. Objective: To verify the outcomes (O) analyzed in randomized controlled trials (C; S) that investigated the use of Xbox/Kinect (I) in patients with stroke (P). Methods: This is a systematic literature review that meets PRISMA standards and the eligibility criteria according to the PICOS strategy. The search procedure was performed by two researchers. The research strategy was repeated in case of divergence. Effect size was calculated by Cohen's formula and Hopkins rank. The risk of individual bias was assessed using PEDro Score and Higgins Classification. Results: The main outcomes were postural balance and activities of daily living, with four studies addressing these variables. However, only one study showed the effect of Xbox/Kinect intervention on balance as large, as in two other studies evaluating manual dexterity and depression, respectively. Conclusion: The greater use of Xbox/Kinect in treating patients after stroke is in recovery of balance and motor function, and the evidence support its application. These findings enable the use of virtual reality technology through Xbox/Kinect in rehabilitation programs, focusing on postural balance and motor skills. However, conclusive results are still not possible. Therefore, caution in the use of this technology is required.
\end{abstract}

Keywords: Virtual Reality; Stroke; Rehabilitation.

\section{RESUMO}

Introdução: Jogos ativos baseados em realidade virtual têm sido amplamente utilizados na reabilitação de muitas condições clínicas. No entanto, estudos sobre a utilização do Xbox/Kinect são raros, e não está clara a aplicabilidade da tecnologia no tratamento de pacientes que tiveram acidente vascular cerebral. Objetivo: Verificar os desfechos (0) analisados em ensaios clínicos randomizados e controlados (C; S), que investigaram a utilização do Xbox/Kinect (I) em pacientes que tiveram acidente vascular cerebral (P). Métodos: Trata-se de uma revisão sistemática da literatura que atende aos padrões do PRISMA e aos critérios de elegibilidade, de acordo com a estratégia PICOS. O procedimento de busca foi realizado por dois pesquisadores e, em caso de divergência, a estratégia de busca foi repetida. 0 tamanho do efeito foi calculado por meio da fórmula de Cohen e da escala de Hopkins. O risco de viés individual foi analisado utilizando o escore PEDro e a classificação de Higgins. Resultados: Os principais desfechos foram o equilíbrio postural e as atividades de vida diária, com quatro estudos abordando essas variáveis. No entanto, apenas um estudo mostrou o efeito da intervenção com Xbox/Kinect sobre o equilíbrio como sendo grande, assim como em dois outros artigos que avaliaram destreza manual e depressão, respectivamente. Conclusão: A utilização mais comum do Xbox/Kinect no tratamento de pacientes que tiveram acidente vascular cerebral acontece na recuperação do equilíbrio e da função motora, e as evidências apoiam o seu uso. Esses achados permitem o uso da tecnologia de realidade virtual por meio do Xbox/ Kinect em programas de reabilitação, com foco no equilíbrio postural e nas habilidades motoras. Porém, resultados conclusivos ainda não são possíveis, o que exige cautela no uso dessa tecnologia.

Palavras-chave: Realidade Virtual; Acidente Vascular Cerebral; Reabilitação.

\footnotetext{
1Universidade Federal Fluminense, Programa de Pós-Graduação em Neurociências/Neurologia, Rio de Janeiro RJ, Brasil.

${ }^{2}$ Centro Universitário FIPMoc, Montes Claros MG, Brasil.

${ }^{3}$ Higher Institute of Educational Sciences, Penafiel, Portugal.

uUniversity Institute of Maia, Maia, Portugal.

${ }^{5}$ Research Centre in Sports Sciences, Health Sciences and Human Development, CIDESD, GERON Research Community, Portugal.

${ }^{6}$ Universidade Metodista de Piracicaba, Programa de Pós-Graduação em Ciências do Movimento Humano, São Paulo SP, Brasil.

7Universidade Estadual de Montes Claros, Programa de Pós-Graduação em Ciências da Saúde, Montes Claros MG, Brasil.

Túlio Brandão XAVIER-ROCHA (D) https://orcid.org/0000-0003-0360-4515; Lara CARNEIRO (D) https://orcid.org/0000-0002-4385-5290;

Gustavo Celestino MARTINS (D) https://orcid.org/0000-0002-7104-1198; Guanis de Barros VILELA-JÚNIOR (D) https://orcid.org/0000-0001-8136-1913;

Ricardo Pablo PASSOS (D) https://orcid.org/0000-0001-6597-9991; Camila Castelo Branco PUPE (D) https://orcid.org/0000-0001-9590-435X;

Osvaldo José Moreira do NASCIMENTO (D) https://orcid.org/0000-0003-3516-485X; Desirée Sant'Ana HAIKAL (D) https://orcid.org/0000-0002-0331-0747; Renato Sobral MONTEIRO-JUNIOR (iD https://orcid.org/0000-0002-8472-262X

Correspondence: Renato Sobral Monteiro Júnior; E-mail: monteirojuniorms@gmail.com
}

Support: Coordenação de Aperfeiçoamento de Pessoal de Nível Superior (CAPES), Conselho Nacional de Desenvolvimento Científico e Tecnológico (CNPq), Fundação de Amparo à Pesquisa do Estado de Minas Gerais (FAPEMIG).

Conflict of interest: There is no conflict of interest to declare.

Received on July 16, 2019; Received in its final form on November 15, 2019; Accepted on December 15, 2019. 
Active games based on virtual reality (exergames) have been often used in the prevention of falls of older people ${ }^{1}$ and in the rehabilitation of patients with several pathological conditions ${ }^{2}$. Despite most commercial devices have not been designed for rehabilitation, they have been effective on several treatments. These activities require wide movements ${ }^{3}$, stimulate balance $\mathrm{e}^{4}$ and motor coordination ${ }^{5}$, and are double tasks ${ }^{6}$, with effects upon physical and cognitive skills.

Exergames have gained popularity with Nintendo Wii launching in $2006^{7}$. Interaction between the user and the games takes place through a wireless control and a force platform, which allow converting the movements into game commands, and most of the times the user is represented by an avatar ${ }^{8}$. Several investigations have been approaching the therapeutic application of exergames, with positive results in several capacities of healthy subjects and in the treatment of patients with physical disabilities, such as stroke, vestibular disorders, other balance alterations, orthopedic problems, among others 9 .

The Xbox 360 Kinect, launched in 2009, has also been used as a therapy. This Microsoft console eliminated users' direct contact with the hardware, and the movements are digitally captured through an infrared camera that enables subject's interaction with the virtual environment through their body image ${ }^{10}$. This console increased the odds of virtual reality in the rehabilitation. However, scarce studies use this technology in specific neurological treatments, as in patients with stroke. The most significant results were found in the improvement of physical functions, physical activity levels, and cognition ${ }^{11,12}$.

The post-stroke patient's disability varies depending on the region of the injury in the central nervous system. These sequelae might be motor, speech, language and/or cognitive deficits. Hemiparesis is common, which might result in the impairment of tonus, reflex and voluntary movements, postural balance and gait, hence causing damage in activities of daily living ${ }^{13}$. Therefore, the use of exergames is a viable strategy, because not only it is recreational, but it also stimulates cognitive functions and promotes movement through game interaction.

The use of Nintendo Wii in the rehabilitation of patients with stroke has been well documented in literature ${ }^{9,14-19}$. Findings on this device and its effects show, mainly, the improvement of postural balance and motor functions. Meanwhile, rare studies have been investigating the use of Xbox/Kinect, especially in the treatment of stroke ${ }^{2,12,17,20}$ in physical and mental rehabilitation. Consequently, this systematic review aims to analyze, according to the PICOS strategy, publications $(\mathrm{C} ; \mathrm{S})$ that addressed the treatment of patients with stroke (P) using the Xbox/Kinect (I), in order to identify the main findings, assessment methods, and games $(\mathrm{O})$.

\section{METHODS}

\section{Type of investigation}

The present study is a systematic literature review that meets the patterns of the Preferred Reporting Items for Systematic Review and Meta-Analyses (PRISMA) ${ }^{21}$.

\section{Eligibility criteria}

Original studies published until October 2018 in English, Portuguese or Spanish were included. Inclusion criteria were used in the search, according to the PICOS ${ }^{22}$ : P - subjects with stroke sequelae; I - treatment with Xbox Kinect; $\mathrm{C}$ comparison group(s); $\mathrm{O}$ - considering the aim of the present study, letter $\mathrm{O}$ from the acronym PICOS has not been a limiting eligibility factor; $\mathrm{S}$ - randomized clinical trials.

\section{Strategy of paper search}

Papers have been researched on PubMed, PEDro, Scopus, Cochrane, Web of Science and Grey literature databases. This procedure was conducted between June and October, 2018. No author was contacted, because all data were available in the articles. For each database, combinations of keywords and English words were used, considering that Portuguese and Spanish written works presented an abstract section. Keywords as "hemiplegia", "stroke", "cerebrovascular accident”, "brain vascular accident”, "paresis", "monoparesis", "hemiparesis", "Xbox" and "Kinect" were used and they should appear on the title, abstract or keywords of papers.

Table 1 shows the research strategy in each database. Search procedure was performed by two browsers (TBXR; GCM), and the research strategy was repeated in case of divergence (Table 1).

\section{Criteria for paper selection}

Selection started by excluding duplicates in databases. Then, titles and abstracts of the remaining papers were analysed. Articles that did not meet the objective of the review, e.g. did not include post-stroke patients who had not performed treatment with Xbox and Kinect, without comparison groups and did not present randomized controlled trials (Figure 1), were not included.

\section{Data collection}

Selected papers were read according to the designed steps. General information of each paper was extracted and tabulated to identify details, objectives, variables, assessment tools, and main results.

\section{Risk of individual bias}

The PEDro scale ${ }^{23}$ was applied to classify the mentioned papers according to an accurate methodology to evidence possible bias. This is an 11-item scale allocating one point 
Table 1. Strategy of search and quantity of papers found per database.

\begin{tabular}{|c|c|c|}
\hline Database & Search & Number of papers found \\
\hline PubMed & $\begin{array}{l}\text { hemiplegia OR hemiparesis OR paresis OR monoparesis OR stroke OR cerebrovascular } \\
\text { accident OR brain vascular accident AND Xbox AND Kinect }\end{array}$ & 18 \\
\hline \multirow{12}{*}{ PEDro } & Stroke AND Kinect & 8 \\
\hline & Stroke AND Xbox & 7 \\
\hline & Hemiplegia AND Xbox & 1 \\
\hline & Hemiplegia AND Kinect & 1 \\
\hline & Paresis AND Xbox & 0 \\
\hline & Paresis AND Kinect & 0 \\
\hline & Hemiparesis AND Xbox & 0 \\
\hline & Hemiparesis AND Kinect & 0 \\
\hline & Cerebrovascular AND Xbox & 0 \\
\hline & Cerebrovascular AND Kinect & 0 \\
\hline & Brain vascular AND Xbox & 0 \\
\hline & Brain vascular AND Kinect & 0 \\
\hline Scopus & $\begin{array}{c}\text { hemiplegia OR hemiparesis OR paresis OR monoparesis OR stroke OR cerebrovascular } \\
\text { accident OR brain vascular accident AND Xbox AND Kinect }\end{array}$ & 10 \\
\hline Cochrane & $\begin{array}{l}\text { hemiplegia OR hemiparesis OR paresis OR monoparesis OR stroke OR cerebrovascular } \\
\text { accident OR brain vascular accident AND Xbox AND Kinect }\end{array}$ & 17 \\
\hline Web of Science & $\begin{array}{l}\text { hemiplegia OR hemiparesis OR paresis OR monoparesis OR stroke OR cerebrovascular } \\
\text { accident OR brain vascular accident AND Xbox AND Kinect }\end{array}$ & 31 \\
\hline
\end{tabular}

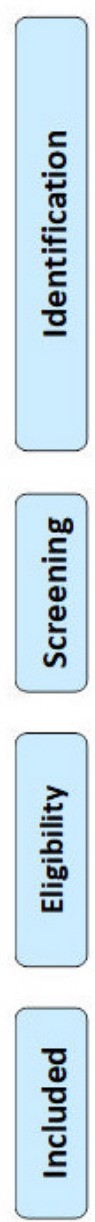

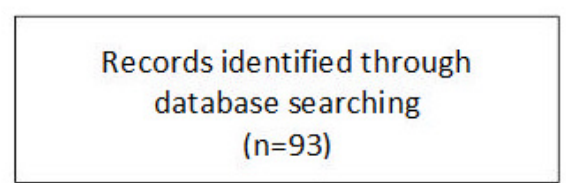
$(n=93)$

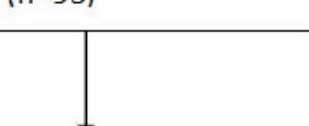

Records after duplicates removed $(n=47)$

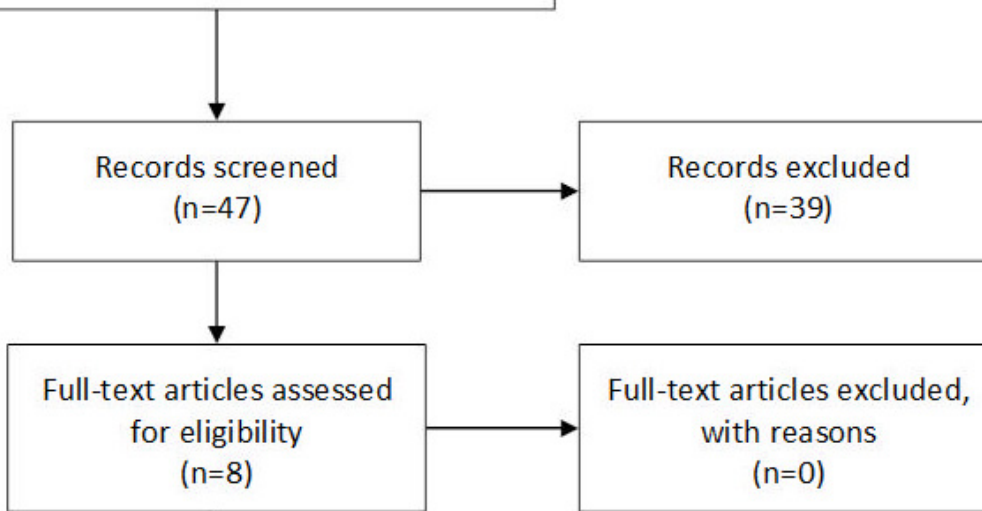

Studies included in qualitative synthesis $(n=8)$ 
to each. The first one is not considered. The items are: $1-$ Eligibility criteria were specified; 2 - Subjects were randomly allocated to groups; 3 - Allocation was concealed; 4 Groups were similar at baseline regarding the most important prognostic indicators; 5 - There was blinding of all subjects; 6 - There was blinding of all therapists who administered the therapy; 7 - There was blinding of all assessors who measured at least one key outcome; 8 - Measures of at least one key outcome were obtained from more than $85 \%$ of the subjects initially allocated to groups; 9 - All subjects for whom outcome measures were available received the treatment or control condition as allocated or, where this was not the case, data for at least one key outcome were analysed by "intention-to-treat"; 10 - The results of between-group statistical comparisons are reported for at least one key outcome; 11 - The study provides both point and variability measures for at least one key outcome.

The Higgins visual scale ${ }^{24}$ was also used to classify studies. This is a validity evaluation of the studies included in the systematic review. It is an eight-item scale that attributes studies qualitative studies (uncertain risk, low risk and high risk of bias). The items are: $1-$ Random sequence generation; 2 - Allocation concealment; 3 - Blinding of participants and personnel; 4 - Blinding of outcome assessment; 5 - Incomplete outcome data; 6 - Selective reporting; 7 Other sources of bias. The graph in Figure 2 presents the result of each item for all the studies.

This stage was merely for rating and was conducted by only one researcher expert in the scale.

\section{Data analysis}

A quantitative approach was conducted through effect size estimation, using the Microsoft Excel ${ }^{\circledR}$ software, with Cohen's formula ${ }^{25}$ and Hopkins classification ${ }^{26}$ for differences between means ${ }^{25}$, scoring the effects as trivial (0-0.19), small (0.2-0.5), moderate (0.6-1.1), high (1.2-1.9), very high (2.0-3.9), almost perfect $(>4)$, and perfect (infinite). Cohen's effect size is calculated according to the sample size, mean and standard deviation of both (Experimental and Control) groups ${ }^{25}$. Hopkins classification allows us to measure the magnitude of the observed effect ${ }^{26}$. Interventions conducted in the studies of this review have also been analyzed, by comparing experimental and control groups on session duration and games used in each study.

\section{RESULTS}

A total of 93 papers was collected from databases, and eight were selected for analysis (Figure 1). Boxes 1 and 2 display extracted and tabulated data of each study.

Data of each paper were extracted and tabulated to identify details regarding the objectives, assessment tools, main findings, and conclusions (Table 2).
Balance has been assessed in three of the eight studies using the Berg Balance Scale (BBS). Lee et al. ${ }^{28}$ observed a significant improvement in Xbox and Control groups, both in post-training and follow-up, although there were no significant differences between groups with trivial and small effects ( $p=0.000 / p=0.003$; ES: 0.10/0.22). Park et al. ${ }^{30}$ have also found significant improvements in both groups $(\mathrm{p}<0.05)$ and a difference between them $(\mathrm{p}<0.05)$, with moderate effect $(\mathrm{ME}$ : 0.65). Malik and Masood ${ }^{31}$ have had great improvements in both groups $(p=0.00)$, with a significant difference in the Experimental Group ( $p=0.001)$, with very large effect (ES: 2.1). Song and Park ${ }^{32}$ used biofeedback to verify the weight distribution between lower limbs and to determine balance skill. Both groups have shown an improvement $(\mathrm{p}<0.05)$ with a significant difference in the group with Xbox training $(p<0.05)$ and small effect (ES: 0.40). Stability limits have been assessed in two studies through Functional Reach Test (FRT) and biofeedback. Lee et al. ${ }^{38}$ have shown no improvements in FRT in intra and inter-groups tests $(\mathrm{p}=0.187 / \mathrm{p}=0.442$; ES: 0.18/0.55). Song and Park $^{32}$ have presented an improvement in the anterior (ES: 0.51; $<<0.05$ ) and the posterior (ES: 0.37; $\mathrm{p}>0.05$ ) limits of stability, as well as significant differences in the Experimental Group $(\mathrm{p}<0.05)$. Both studies diverge on the results, despite their small effect size.

Mobility/gait has also been evaluated in three studies through Timed Up and Go (TUG), 10-meters Walking Test (10mWT), and other walking tests. Lee et al. ${ }^{28}$ assessed simultaneously gait and a cognitive task (calculation) and have found a reduction in time performance for the group with Xbox training ( $p=0.009$; ES: 0.03/0.00). However, both between and inter groups presented a difference on the trivial effect. Park et al. ${ }^{30}$, with the same tests, have shown an improvement in both groups ( $\mathrm{p}<0.05$ ), and the Experimental Group presented significant differences $(\mathrm{p}<0.05)$, with trivial effect on TUG (ES: 0.13) and small on 10 mWT (ES: -0.25). In Song and Park study ${ }^{32}$, both groups presented a time reduction in performance on TUG and 10 mWT ( $<<0.05)$, in which the Experimental Group had a significant difference $(\mathrm{p}<0.05)$, but with a small to moderate effect (ES respectively: $-0.34 ;-0.79$ ).

Functional independence and activities of daily living were assessed in four of the eight studies. Lee et al. ${ }^{28}$ used Modified Barthel Index (MBI) $(p=0.494 / p=0.575$; ES: $0.15 / 0.04)$ and Activities-specific balance confidence scale (ABC) $(\mathrm{p}=0.963 / 0.528$; ES: 0.22/0.07), with no differences between them and inter/intra groups. The other authors used Functional Independence Measure (FIM). Afsar et al. ${ }^{27}$ have found no differences in both groups after the intervention $(p=0.40$ and $p=0.95)$ nor between them $(p>0.677)$. Türkbey et al. ${ }^{29}$ presented significant improvements in both groups $(p=0.018)$ without differences between them ( $p>0.05)$, with a small effect size (ES: 0.32). Lee ${ }^{33}$ observed significant differences in both groups after the intervention $(p<0.05)$, but none between groups $(p>0.05)$ and a small effect size (ES: 0.36). 
Table 2. General data of selected studies.

\begin{tabular}{|c|c|c|c|c|}
\hline Authors & Objective & Variables & Instruments & Results \\
\hline Ikbali Afsar et al. ${ }^{27}$ & $\begin{array}{l}\text { To evaluate the effect } \\
\text { of Xbox Kinect training } \\
\text { added to standard } \\
\text { rehabilitation on upper } \\
\text { limb motor functions of } \\
\text { sub-acute stroke patients }\end{array}$ & $\begin{array}{l}\text { Motor function of } \\
\text { upper limbs; motor } \\
\text { development; gross } \\
\text { motor skill; and activities } \\
\text { of daily living }\end{array}$ & $\begin{array}{l}\text { Fugl-Meyer assessment } \\
\text { Upper extremity (FMA- } \\
\text { UE); Brunnstrom stage } \\
\text { recovery (BSR); Box } \\
\text { and Block test (BBT); } \\
\text { Functional Independence } \\
\text { Measure (FIM) }\end{array}$ & $\begin{array}{l}\text { Significant improvements } \\
\text { in both groups in post- } \\
\text { training in all the variables. } \\
\text { The improvements on the } \\
\text { Brunnstrom Stage of upper } \\
\text { extremity, FMA-UE and BBT } \\
\text { were significantly higher in the } \\
\text { Experimental Group, but not in } \\
\text { the Brunnstrom stage of Hand, } \\
\text { FIM and FMA }\end{array}$ \\
\hline Lee et al. ${ }^{28}$ & $\begin{array}{l}\text { To investigate the effects } \\
\text { of training with Xbox } \\
\text { Kinect associated with } \\
\text { the standard strength } \\
\text { training, resistance, gait, } \\
\text { and activities of daily } \\
\text { living in balance skill }\end{array}$ & $\begin{array}{l}\text { Balance; stability } \\
\text { limit; mobility and } \\
\text { double task; functional } \\
\text { independence; activities } \\
\text { of daily living; quality } \\
\text { of life }\end{array}$ & $\begin{array}{l}\text { Berg balance scale, } \\
\text { Functional reach test, } \\
\text { Timed up and go- } \\
\text { cognitive (TUG-cog); } \\
\text { Modified Barthel Index; } \\
\text { Activities-specific } \\
\text { balance confidence } \\
\text { scale (ABC); Stroke } \\
\text { Impact Scale }\end{array}$ & $\begin{array}{l}\text { Significant improvements on } \\
\text { BBS and TUG-cog in both groups, } \\
\text { although without significant } \\
\text { differences between groups. } \\
\text { The other tests presented no } \\
\text { significant differences }\end{array}$ \\
\hline
\end{tabular}

To evaluate both the

Türkbey et al. ${ }^{29}$ feasibility and security of Xbox Kinect in upper limb training
Dexterity; motor function; functional independence; muscle tone; motor recovery
Box and Block test (BBT); Wolf motor Function test (WMFT); Functional Independence Measure (FIM); Modified Ashworth Scale (MAS); Brunnstrom motor recovery stages (BMRS)

\begin{tabular}{|c|c|c|c|c|}
\hline Park et al. ${ }^{30}$ & $\begin{array}{l}\text { To assess the effects } \\
\text { of additional training } \\
\text { of virtual reality with } \\
\text { Xbox Kinect on motor } \\
\text { recovery of lower limbs } \\
\text { in stroke patients with } \\
\text { chronic hemiplegia }\end{array}$ & $\begin{array}{l}\text { Motor recovery; } \\
\text { balance; gait }\end{array}$ & $\begin{array}{l}\text { Fugl-Meyer lower } \\
\text { extremities assessment } \\
\text { (FMA-LE); Box and Block } \\
\text { test (BBT); Timed Up } \\
\text { and Go (TUG); } 10-\text { meter } \\
\text { Walking Test (10 mWT) }\end{array}$ & $\begin{array}{l}\text { Improvements on FMA-LE, } \\
\text { BBT, TUG and } 10 \text { mWT after } \\
\text { intervention on both groups. } \\
\text { Only FMA-LE presented no } \\
\text { differences between groups }\end{array}$ \\
\hline $\begin{array}{l}\text { Malik and } \\
\text { Massod }^{31}\end{array}$ & $\begin{array}{l}\text { To compare the results } \\
\text { of balance with virtual } \\
\text { reality and task- } \\
\text { oriented training in } \\
\text { stroke patients }\end{array}$ & Balance and mobility & $\begin{array}{l}\text { Berg Balance Scale } \\
\text { (BBS) }\end{array}$ & $\begin{array}{c}\text { Significant improvement on both } \\
\text { groups after the interventions, } \\
\text { and significantly better on the } \\
\text { Experimental Group }\end{array}$ \\
\hline Song and Park ${ }^{32}$ & $\begin{array}{l}\text { To determine training } \\
\text { effects with virtual } \\
\text { reality games over } \\
\text { balance and gait skill, } \\
\text { as well as psychological } \\
\text { characteristics }\end{array}$ & $\begin{array}{l}\text { Weight distribution } \\
\text { ratio; anterior limit of } \\
\text { stability; posterior Limit } \\
\text { of stability; gait skill; } \\
\text { mental health }\end{array}$ & $\begin{array}{c}\text { Biofeedback analysis } \\
\text { system; Timed Up and } \\
\text { Go (TUG); } \\
\text { 10-m walking test; } \\
\text { Beck Depression } \\
\text { Inventory and } \\
\text { relationship change } \\
\text { scale (psychological) }\end{array}$ & $\begin{array}{l}\text { Both groups have shown } \\
\text { significant improvements in all } \\
\text { variables after the intervention, } \\
\text { although with significant } \\
\text { differences between groups }\end{array}$ \\
\hline $\operatorname{Lee}^{33}$ & $\begin{array}{l}\text { To investigate the } \\
\text { effects of training with } \\
\text { Xbox Kinect on strength } \\
\text { and muscle tone, and } \\
\text { activities of daily living }\end{array}$ & $\begin{array}{l}\text { Muscle strength; muscle } \\
\text { tone; activities of } \\
\text { daily living }\end{array}$ & $\begin{array}{l}\text { Manual Muscle test; } \\
\text { Modified Ashworth } \\
\text { Scale; Functional } \\
\text { Independence Measure } \\
\text { (FIM) }\end{array}$ & $\begin{array}{l}\text { Significant improvements } \\
\text { on strength of shoulder and } \\
\text { elbow flexion-extension and } \\
\text { FIM scores of the Experimental } \\
\text { Group. Control Group has shown } \\
\text { improvements on strength of } \\
\text { elbow extension and FIM. No } \\
\text { significant differences were } \\
\text { found between groups }\end{array}$ \\
\hline Sin and $\mathrm{Lee}^{34}$ & $\begin{array}{l}\text { To investigate the effects } \\
\text { of additional training } \\
\text { with Xbox Kinect on } \\
\text { upper limb function }\end{array}$ & $\begin{array}{l}\text { Active amplitude of } \\
\text { movement, motor } \\
\text { function; manual dexterity }\end{array}$ & $\begin{array}{l}\text { Active range of motion } \\
\text { (ROM); Fugl-Meyer } \\
\text { Assessment (FMA); Box } \\
\text { and Block Test (BBT) }\end{array}$ & $\begin{array}{l}\text { Both groups have shown } \\
\text { significant improvements on } \\
\text { active amplitude of movement } \\
\text { of shoulder flexion, extension } \\
\text { and abduction, elbow flexion, } \\
\text { wrist flexion and extension, } \\
\text { FMA and BBT. No significant } \\
\text { improvements were found } \\
\text { between groups on ADM wrist }\end{array}$ \\
\hline
\end{tabular}

Significant improvements only on BBS and TUG-cog in both groups, although without significant differences between them. No significant differences have been found in the other tests

Improvements on FMA-LE, Only FMA-LE presented no test (BBT); Timed Up and Go (TUG); 10-meter Walking Test (10 mWT) d significantly better on the Experimental Group

. 
Motor function was evaluated by four studies. Afsar et al. ${ }^{27}$ assessed upper limbs through Fugl-Meyer Assessment (FMA), with a significant improvement in both groups $(\mathrm{p}=0.04)$. However, there was no significant difference between groups $(\mathrm{p}<0.57)$ and a and moderate effect (ES: 0.66). Park et al. ${ }^{30}$ evaluated lower limbs through the same test, with significant improvements in both groups $(\mathrm{p}<0.05)$, but without differences between groups ( $>>0.05$ ) and moderate effect (ES: 0.37). Sin and Lee ${ }^{34}$ used the full version test and obtained significant improvements in both groups $(\mathrm{p}<0.05)$. The Experimental Group had a significant difference and moderate effect ( $\mathrm{p}=0.041$; ES: 1.06). Türkbey et al. ${ }^{29}$ used Wolf Motor Function Test (WMFT) and have also obtained significant improvements in both Experimental $(\mathrm{p}=0.005)$ and Control ( $\mathrm{p}=0.041$ ) groups, besides a significant difference in the Experimental Group ( $\mathrm{p}=0.014)$ and moderate effect (ES: 0.79) in the group that trained with Xbox Kinect.
Three studies assessed gross motor skill with the Box and Block Test (BBT). All the studies have shown that the Xbox group exhibited significant improvements in comparison with the Control Group. Afsar et al. ${ }^{27}$ have noticed a significant improvement $(\mathrm{p}=0.04)$ in both groups, significant differences between groups $(\mathrm{p}=0.007)$ and prominence by the Experimental Group and large effect (ES: 1.58). Türkbey et al. ${ }^{29}$ have found a significant improvement in both the Experimental $(\mathrm{p}=0.005)$ and Control $(\mathrm{p}=0.025)$ Groups, significant differences between groups $(\mathrm{p}=0.005)$ and the Experimental Group leading and a moderate effect (ES: 0.69). Sin and $\mathrm{Lee}^{34}$ obtained a significant improvement in the Experimental $(\mathrm{p}=0.001)$ and Control Groups $(\mathrm{p}=0.005)$; significant differences between groups ( $\mathrm{p}=0.043)$, mainly in the Experimental Group, and moderate effect (ES: 0.65). Table 3 shows all data collection.

Table 3. Data on the intervention of Experimental and Control Groups.

\begin{tabular}{|c|c|c|c|c|c|}
\hline Author & $\begin{array}{l}\text { Intervention } \\
\text { Experimental } \\
\text { Group }\end{array}$ & Games & $\begin{array}{l}\text { Number of } \\
\text { sessions } \\
\text { (time-min) }\end{array}$ & $\begin{array}{l}\text { Intervention } \\
\text { Control Group }\end{array}$ & $\begin{array}{l}\text { Number of } \\
\text { sessions } \\
\text { (time-min) }\end{array}$ \\
\hline $\begin{array}{l}\text { Afsar } \\
\text { et al. }{ }^{28}\end{array}$ & $\begin{array}{l}\text { Standard } \\
\text { occupational } \\
\text { therapy + Xbox }\end{array}$ & $\begin{array}{c}\text { Mouse Mayhem, Traffic } \\
\text { Control, Balloon Buster, } \\
\text { and Mathercising from Dr. } \\
\text { Kawashima's Body and Brain } \\
\text { Exercise package }\end{array}$ & $\begin{array}{l}20 \text { (90'), five } \\
\text { times a week }\end{array}$ & $\begin{array}{l}\text { Control of static and dynamic } \\
\text { position, balance training, } \\
\text { weight loss, functional training } \\
\text { (activities of daily living), } \\
\text { proprioceptive neuromuscular } \\
\text { facilitation, neurodevelopmental } \\
\text { treatment principles }\end{array}$ & $\begin{array}{l}20 \text { (60'), five } \\
\text { times a week }\end{array}$ \\
\hline $\begin{array}{l}\text { Lee } \\
\text { et al. }{ }^{29}\end{array}$ & $\begin{array}{l}\text { Standard therapy } \\
\text { (as in Control } \\
\text { Group) + Xbox }\end{array}$ & $\begin{array}{c}\text { Darts; Golf; Bowling; Virtual } \\
\text { smash; Light race; Space } \\
\text { Pop; Rally Ball; Table Tennis; } \\
\text { River rush }\end{array}$ & $\begin{array}{c}12 \text { (90'), twice } \\
\text { a week }\end{array}$ & $\begin{array}{c}\text { Balance training, weight loss, } \\
\text { postural transition, postural } \\
\text { disturbances, cognitive- } \\
\text { motor training }\end{array}$ & $\begin{array}{c}12\left(90^{\prime}\right) \text {, twice } \\
\text { a week }\end{array}$ \\
\hline $\begin{array}{l}\text { Türkbey } \\
\text { et al. }{ }^{30}\end{array}$ & $\begin{array}{l}\text { Standard therapy } \\
\text { (as in Control } \\
\text { Group) }+ \text { Xbox }\end{array}$ & $\begin{array}{c}\text { Bowling (Kinect sports), } \\
\text { Mouse Mayen ( } \mathrm{Dr} \\
\text { Kawashima's body and brain } \\
\text { exercise package) }\end{array}$ & $\begin{array}{l}20(120 \text { '), five } \\
\text { times a week }\end{array}$ & $\begin{array}{l}\text { Passive and active exercises } \\
\text { for ADM, stretching and } \\
\text { muscle reinforcement, } \\
\text { neurophysiological exercises, } \\
\text { gait training and balance and } \\
\text { functional activities }\end{array}$ & $\begin{array}{c}20\left(60^{\prime}\right) \text {, five } \\
\text { times a week }\end{array}$ \\
\hline $\begin{array}{l}\text { Park } \\
\text { et al. }{ }^{31}\end{array}$ & $\begin{array}{l}\text { Standard therapy } \\
\text { (as in Control } \\
\text { Group) + Xbox }\end{array}$ & $\begin{array}{l}\text { Boxing, table tennis, } \\
\text { and soccer from the Kinect } \\
\text { Sports Pack; and golf, ski, } \\
\text { and football from the Kinect } \\
\text { Sports Pack } 2\end{array}$ & $\begin{array}{l}30(30 \text { '), five } \\
\text { times a week }\end{array}$ & $\begin{array}{l}\text { Exercises for ADM, muscle } \\
\text { reinforcement, functional } \\
\text { training of balance and } \\
\text { gait. Neurodevelopment } \\
\text { treatment and proprioceptive } \\
\text { neuromuscular facilitation }\end{array}$ & $\begin{array}{l}\left.30 \text { ( } 30^{\prime}\right) \text {, five } \\
\text { times a week }\end{array}$ \\
\hline $\begin{array}{l}\text { Malik and } \\
\text { Masood }^{32}\end{array}$ & $\begin{array}{l}\text { Task-oriented } \\
\text { therapy (as in } \\
\text { Control Group) } \\
\quad+\text { Xbox }\end{array}$ & $\begin{array}{c}20,000 \\
\text { Water leaks, River rush and } \\
\text { Reflex ridge }\end{array}$ & $\begin{array}{l}18 \\
\text { (undetermined) } \\
\text { three times } \\
\text { a week }\end{array}$ & $\begin{array}{l}\text { Lateral gait, gait with hip flexion, } \\
\text { gait on different surfaces, } \\
\text { transfer from sitting position to } \\
\text { standing position; grip an object, } \\
\text { anterior reach }\end{array}$ & $\begin{array}{l}18 \\
\text { (undetermined), } \\
\text { three times } \\
\text { a week }\end{array}$ \\
\hline $\begin{array}{l}\text { Song and } \\
\text { Park }{ }^{33}\end{array}$ & & $\begin{array}{l}\text { Kinect Sport, Kinect Sport } \\
\text { Season 2, Kinect Adventure } \\
\text { and Kinect Gunstringer }\end{array}$ & $\begin{array}{c}40(30 \text { '), five } \\
\text { times a week }\end{array}$ & Training with cycle ergometer & $\begin{array}{c}40 \text { (30'), five } \\
\text { times a week }\end{array}$ \\
\hline $\operatorname{Lee}^{34}$ & $\begin{array}{l}\text { Occupational } \\
\text { therapy + Xbox }\end{array}$ & $\begin{array}{c}\text { Kinect sports (Boxing } \\
\text { and Bowling) and Kinect } \\
\text { adventure (Rally Ball, 20,000 } \\
\text { Leaks, and Space Pop) }\end{array}$ & $\begin{array}{l}18\left(60^{\prime}\right) \text {, three } \\
\text { times a week }\end{array}$ & $\begin{array}{l}\text { Occupational therapy (without } \\
\text { treatment description) }\end{array}$ & $\begin{array}{l}18\left(30^{\prime}\right) \text {, three } \\
\text { times a week }\end{array}$ \\
\hline $\begin{array}{l}\text { Sin and } \\
\operatorname{Lee}^{35}\end{array}$ & $\begin{array}{c}\text { Standard } \\
\text { occupational } \\
\text { therapy + Xbox }\end{array}$ & $\begin{array}{l}\text { Boxing and Bowling in the } \\
\text { Kinect sports pack and } \\
\text { Rally Ball, 20,000 Leaks, } \\
\text { and Space Pop in the Kinect } \\
\text { adventure pack }\end{array}$ & $\begin{array}{l}18(30 \text { '), three } \\
\text { times a week }\end{array}$ & $\begin{array}{l}\text { Passive and active exercises } \\
\text { for ADM, stretching and muscle } \\
\text { reinforcement }\end{array}$ & $\begin{array}{l}18\left(30^{\prime}\right) \text {, three } \\
\text { times a week }\end{array}$ \\
\hline
\end{tabular}


Six studies presented a training volume higher in the Experimental Group rather than in the Control Group, most of the times the double of time ${ }^{29,30,31,33,34}$. Four of the eight studies used bowling ${ }^{28,29,33,34}$, and only two ${ }^{33,34}$ used the same game battery, comprising 20,000 water leaks, bowling, boxing, rally ball and space pop. One study ${ }^{32}$ was unclear about the games used, despite citing the selected packages (Kinect Sports 1 and 2, Kinect Adventure and Kinect Gunstringer).

Although authors had presented data as significant, most of the results have shown a small effect on the intervention with Xbox. The BBT conducted by Afsar et al. ${ }^{27}$ and the Beck Depression Inventory (BDI), in the study by Song and Park $^{32}$ had a large effect, respectively (ES: 1.58; -1.42); The BBS by Malik and Masood ${ }^{31}$ had a very large effect (ES: 2.1), as presented in Table 4. Results of tests conducted in all the above-mentioned studies have shown a significant improvement of balance skill, gait and patients' motor function after the intervention that varied between 12 and 40 sessions, twice to five times a week, with a duration of 30 to 90 minutes.

Methodological rigour of studies has been assessed with the PEDro scale ${ }^{23}$ (Table 4), which shows scores between 6 and 8 points, and the Higgins visual scale ${ }^{24}$ (Figure 2) that introduces studies presenting unclear and low risk of bias.

Table 4. The PEDro Score.

\begin{tabular}{|c|c|}
\hline Author (year) & Score \\
\hline Afsar et al. ${ }^{29}$ & 7 \\
\hline Lee et al. ${ }^{30}$ & 8 \\
\hline Türkbey et al. ${ }^{31}$ & 8 \\
\hline Park et al..$^{32}$ & 7 \\
\hline Malik and Masood ${ }^{33}$ & 6 \\
\hline Song and Park 34 & 6 \\
\hline $\mathrm{Lee}^{35}$ & 7 \\
\hline Sin and $\operatorname{Lee}^{36}$ & 6 \\
\hline
\end{tabular}

\section{DISCUSSION}

This systematic review shows the details of interventions with Xbox/Kinect in patients with stroke. Postural balance ${ }^{29,31-33}$, the ability to perform activities of daily living $28,29,30,34$, general motor function ${ }^{34}$, upper limb motor function ${ }^{28}$, lower limb motor function ${ }^{31}$, gross motor skill ${ }^{28,30,34}$, motor development ${ }^{28,30}$, gait $^{31,33}$, quality of life $^{29}$, muscle tone ${ }^{34}$, mobility ${ }^{32}$, amplitude of movement $^{34}$, strength ${ }^{33}$, and depression ${ }^{32}$ have been investigated. Despite the probable clinical application related by the authors, findings have not shown, individually, differences between the intervention with Xbox/Kinect and standard treatment with functional exercises and kinesiotherapy. This finding shows that there might be a likely resemblance between the intervention with Xbox/Kinect and standard rehabilitation, especially when analyzing the effect size between groups (small/large) in different variables. The use of virtual reality-based games provides a multisensory retro feeding that improves motor refinement ${ }^{35-38}$, possibly through neuroplasticity mechanisms ${ }^{38,39}$. The improvement of physical and cognitive functions varies and occurs at short and long terms on stroke patients ${ }^{1,11}$. Specifically, benefits of exergames include the increase of gait velocity, balance and mobility and motivation to treatment ${ }^{20}$. However, the guidelines from the American Heart Association and the American Stroke Association ${ }^{13}$ call the attention to the use of this technology in the rehabilitation of stroke patients. It presents B level, class IIb, in gait improvement and spatial orientation, and IIa class on upper limb movement practice. B level indicates that the studies have been conducted with limited populations and simply randomized or not. Class IIa indicates favorable recommendations to the procedure, with some opposite evidence, whereas class IIb indicates that the utility or effectiveness of the procedure is less established and involves higher opposite evidence ${ }^{13}$.

A systematic review ${ }^{17}$ has evidenced no advantage of the rehabilitation with exergames in relation to the standard therapy on upper limb mobility and activities of daily living. According to the authors, there is insufficient evidence to conclude on the use of virtual reality-based games on gait velocity and postural balance. These data corroborate partially with the

Random sequence generation (selection bias)

Allocation concealment (selection bias)

Blinding of participants and personnel (Performance Bias)

Blinding of outcome assessment (detection bias)

Incomplete outcome data (attrition bias)

Selective reporting (reporting bias)

Other Bias

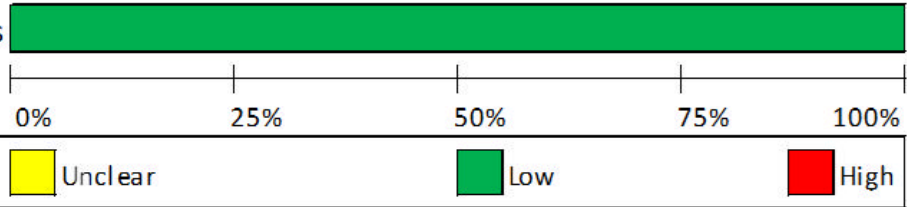

Figure 2. Risk of BIAS according to the Higgins scale. 
effect size findings of the present study. Nevertheless, the studies present no discussion about the limitations on the use of $\mathrm{Xbox} /$ Kinect; therefore, we suggest that the use of this device in certain treatments (e.g. neurological patients) might be difficult due to the therapist's impossibility to be closer to the patient's body, as the digitalization of user's body image suffers interferences with another person's presence. Maybe this might be one of the reasons for the scarce amount of investigations on this device. In case of this interference, the sensor needs to be calibrated again as mentioned by Lee ${ }^{33}$.

All the studies assessed in this review presented arguments in favor of exergames in the rehabilitation of these patients. Even though there was study heterogeneity, clinical effects were observed and should be considered. A large ${ }^{28}$ and moderate ${ }^{30,34}$ effect size has been found on the motor function assessed with the BBT on two studies that used this device. Furthermore, one of the studies presented depression with a large opposite effect ${ }^{32}$.

Balance presented an effect size from trivial to large $\mathrm{e}^{29,31,32}$, which shows a great heterogeneity of results. This variability can also be observed in gait, which has presented an effect size varying from trivial to moderate $\mathrm{e}^{29,31,33}$. Therefore, there are no consistent data to sustain the efficacy of rehabilitation with Xbox in many variables.

The largest effect size was found on postural balance, in the study where participants performed 18 intervention sessions, three times a week, using the games: 20,000 water leaks, reflex ridge, and river rush ${ }^{32}$. However, the duration of the treatment session was not mentioned. The largest number of sessions was 40, among all the studies analyzed with a 30-minute duration, using Kinect Adventure, Kinect Sports 1 and 2, and Kinect Gunstringer ${ }^{33}$. Authors have found a large effect of improvement on depression symptoms and moderate effect on gait improvement ${ }^{33}$.

Limitations of the present study include the impossibility of a data meta-analysis, as studies present different variables and methods. On the other hand, the classification of volunteers through questionnaires and divergent tests hampers comparison of results. The use of different games does not allow the determination of which have influenced greater upon results, as although similar, they demand distinct skills and tasks. The small number of randomized and controlled studies published on this scope increases the disparity of papers investigated herein, which reduces the possibility of an estimation of a grouped effect.

Other important limitations of the included studies were: lack of analysis regarding the injury location; number and type of sequelae. Furthermore, only one study analyzed depression $^{31}$, and none of them verified anxiety symptoms, which could affect rehabilitation engagement negatively. Furthermore, these studies did not analyze comorbidities. Procedures of electromyography analyses were also not clear, which hindered the replication of these methods.

The use of Xbox/Kinect for the rehabilitation of stroke patients is a recent topic. The first controlled and randomized studies were published in 2013. Moreover, the studies here selected presented small samples, and the majority comprised less than 30 volunteers. The greater use of Xbox Kinect with more significant results in the treatment of stroke patients was in the recovery of motor function and postural balance. Nevertheless, conclusive findings on these and other variables were not possible yet, which increases the necessity for caution with this device in the rehabilitation. Further investigation with larger samples is recommended.

\section{References}

1. Choi SD, Guo L, Kang D, Xiong S. Exergame technology and interactive interventions for elderly fall prevention: A systematic literature review. Appl Ergon. 2017;65:570-581. https://doi.org/10.1016/J. APERG0.2016.10.013

2. Zeng N, Pope Z, Lee JE, Gao Z. A systematic review of active video games on rehabilitative outcomes among older patients. J Sport Heal Sci. 2017 Mar;6(1):33-43. https://doi.org/10.1016/j.jshs.2016.12.002

3. Tahmosybayat R, Baker K, Godfrey A, Caplan N, Barry G. Movements of older adults during exergaming interventions that are associated with the Systems Framework for Postural Control: A systematic review. Maturitas. 2018 May;111:90-9. https://doi.org/10.1016/j. maturitas.2018.03.005

4. Hondori HM, Khademi M. A review on technical and clinical impact of microsoft Kinect on physical therapy and rehabilitation.J Med Eng. 2014;2014. https://doi.org/10.1155/2014/846514

5. di Tore PA, Raiola G. Exergames and motor skills learning: a brief summary. Int Res J Appl Basic Sci. 2012;3(6):1161-4.

6. Tait JL, Duckham RL, Milte CM, Main LC, Daly RM. Influence of sequential vs. simultaneous dual-task exercise training on cognitive function in older adults. Front Aging Neurosci. 2017 Nov;9. https:// doi.org/10.3389/fnagi.2017.00368
7. Pessoa TM, Coutinho DS, Pereira VM, De Oliveira Ribeiro NP, Nardi AE, De Oliveira e Silva AC. The Nintendo Wii as a tool for neurocognitive rehabilitation, training and health promotion. Comput Human Behav. 2014 Feb;31(1):384-92. https://doi.org/10.1016/j.chb.2013.10.025

8. Alves MLM, Mesquita BS, Morais WS, Leal JC, Satler CE, dos Santos Mendes FA. Nintendo WiiTM versus Xbox KinectTM for assisting people with parkinson's disease. Percept Mot Skills. 2018 Apr;125(3):546-65. https://doi.org/10.1177/0031512518769204

9. Tripette J, Murakami H, Ryan KR, Ohta Y, Miyachi M. The contribution of Nintendo Wii Fit series in the field of health: a systematic review and meta-analysis. Peer J. 2017;5:e3600. https://doi.org/10.7717/ peerj.3600

10. Bonnechère B, Jansen B, Omelina L, Sholukha V, Jan SVS, Bruxelles D. Patients' follow-up using biomechanical analysis of rehabilitation exercises. Int J Serious Games. 2017 Mar;4(1):3-13. https://doi. org/10.17083/ijsg.v4i1.121

11. Aminov A, Rogers JM, Middleton S, Caeyenberghs K, Wilson PH. What do randomized controlled trials say about virtual rehabilitation in stroke? A systematic literature review and meta-analysis of upperlimb and cognitive outcomes. J NeuroEngineering Rehabil. 2018 Mar;15(1):29. https://doi.org/10.1186/s12984-018-0370-2 
12. Bonnechère $B$, Jansen $B$, Omelina L, Van Sint Jan S. The use of commercial video games in rehabilitation: A systematic review. Int J Rehabil Res. 2016 Dec;39(4):277-90. https://doi.org/10.1097/ MRR.0000000000000190

13. Winstein CJ, Stein J, Arena R, et al. Guidelines for Adult Stroke Rehabilitation and Recovery: A Guideline for Healthcare Professionals from the American Heart Association/American Stroke Association. Stroke. 2016 Jun;47(6):e98-169. https://doi.org/10.1161/ STR.0000000000000098

14. dos Santos LRA, Carregosa AA, Masruha MR, Coêlho MLS, Ferraz DD, Ribeiro NMS, et al. The use of Nintendo Wii in the rehabilitation of poststroke patients: a systematic review. J Stroke Cerebrovasc Dis. 2015;24(10):2298-305. https://doi.org/10.1016/j. jstrokecerebrovasdis.2015.06.010

15. Thomson K, Pollock A, Bugge C, Brady MC. Commercial gaming devices for stroke upper limb rehabilitation: a survey of current practice. Int J Stroke. 2016;11(6):454-61. https://doi.org/10.3109/174 83107.2015.1005031

16. Cheok G, Tan D, Low A, Hewitt J. Is Nintendo Wii an effective intervention for individuals with stroke? a systematic review and meta-analysis. J Am Med Dir Assoc. 2015 Nov;16(11):923-32. https:// doi.org/10.1016/j.jamda.2015.06.010

17. Laver KKEK, Lange B, George S, Deutsch JEJ, Saposnik G, Crotty M. Virtual reality for stroke rehabilitation. Cochrane Database Syst Rev. 2017;(11):CD008349. https://doi.org/10.1002/14651858.CD008349

18. Lohse KR, Hilderman CGE, Cheung KL, Tatla S, Van der Loos HFM. Virtual reality therapy for adults post-stroke: a systematic review and meta-analysis exploring virtual environments and commercial games in therapy. PLoS One. 2014 Mar;9(3):e93318. https://doi. org/10.1371/journal.pone.0093318

19. Li Z, Han X-G, Sheng J, Ma S-J. Virtual reality for improving balance in patients after stroke: A systematic review and meta-analysis. Clin Rehabil. 2016 Jul;30(5):432-40. https://doi. org/10.1177/0269215515593611

20. Corbetta D, Imeri F, Gatti R. Rehabilitation that incorporates virtual reality is more effective than standard rehabilitation for improving walking speed, balance and mobility after stroke: A systematic review. J Physiother. 2015 Jul;61(3):117-24. https://doi.org/10.1016/j. jphys.2015.05.017

21. Moher D, Liberati A, Tetzlaff J, Altman DG, The PRISMA Group. Preferred reporting items for systematic reviews and meta-analyses: The PRISMA statement. PLoS Med. 2009 Jul;6(7):e1000097. https:// doi.org/10.1371/journal.pmed.1000097

22. Methley AM, Campbell S, Chew-Graham C, McNally R, Cheraghi-Sohi S. PICO, PICOS and SPIDER: A comparison study of specificity and sensitivity in three search tools for qualitative systematic reviews. BMC Health Serv Res. 2014;14(1):579. https://doi.org/10.1186/ s12913-014-0579-0

23. PEDro Scale. Available from: https://www.pedro.org.au/english/ downloads/pedro-scale/.

24. Higgins JPT, Altman DG, Sterne JAC, editors. Chapter 8: Assessing risk of bias in included studies. In: Higgins JPT, Green S (editors) Cochrane Handbook for Systematic Reviews of Interventions Version 5.1.0 (updated March 2011). The Cochrane Collaboration, 2011. Available from: www.handbook.cochrane.org.
25. Cohen J. A power primer. Psychol Bull. 1992;112(1):155-9. https://doi. org/10.1037//0033-2909.112.1.155

26. Hopkins W. New view of statistics: Effect magnitudes. Sportscience. 2002. Available from: http://www.sportsci.org/resource/stats/ effectmag.html.

27. Ikbali Afsar S, Mirzayev I, Umit Yemisci O, Cosar Saracgil SN. Virtual reality in upper extremity rehabilitation of stroke patients: a randomized controlled trial J Stroke Cerebrovasc Dis. 2018 Dec;27(12):3473-8. https://doi.org/10.1016/j. jstrokecerebrovasdis.2018.08.007

28. Lee H-C, Huang $\mathrm{C}-\mathrm{L}$, Ho S-H, Sung W-H. The effect of a virtual reality game intervention on balance for patients with stroke: a randomized controlled trial. Games Health J. 2017 Oct;6(5):303-11. https://doi. org/10.1089/g4h.2016.0109

29. Türkbey T, Kutlay S, Gök H. Clinical feasibility of Xbox KinectTM training for stroke rehabilitation: A single-blind randomized controlled pilot study. J Rehabil Med. 2017;49(1):22-9. https://doi. org/10.2340/16501977-2183

30. Park D-S, Lee D-G, Lee K, Lee G. Effects of Virtual reality training using xbox kinect on motor function in stroke survivors: a preliminary study. J Stroke Cerebrovasc Dis. 2017 Jun;26(10):2313-9. https://doi. org/10.1016/j.jstrokecerebrovasdis.2017.05.019

31. Malik AN, Masood T. Virtual reality training improves balance outcome in stroke patients. Int J Rehabil Sci. 2016;05(02):8-12.

32. Song G bin, Park E cho. Effect of virtual reality games on stroke patients' balance, gait, depression, and interpersonal relationships.J Phys Ther Sci. 2015;27(7):2057-60. https://doi.org/10.1589/jpts.27.2057

33. Lee G. Effects of training using video games on the muscle strength, muscle tone, and activities of daily living of chronic stroke patients. $J$ Phys Ther Sci. 2013 Oct;25(5):595-7. https://doi.org/10.1589/jpts.25.595

34. $\operatorname{Sin} \mathrm{H}$, Lee $\mathrm{G}$. Additional virtual reality training using Xbox kinect in stroke survivors with hemiplegia. Am J Phys Med Rehabil. 2013;92(10):871-80. https://doi.org/10.1097/ PHM.0b013e3182a38e40

35. Viñas-Diz S, Sobrido-Prieto M. Virtual reality for therapeutic purposes in stroke: A systematic review. Neurol (English Ed.). 2016 May;31(4):255-77. https://doi.org/10.1016/j.nrleng.2015.06.007

36. Gatica-Rojas V, Méndez-Rebolledo G. Virtual reality interface devices in the reorganization of neural networks in the brain of patients with neurological diseases. Neural Regen Res. 2014 May;9(8):888-96. https://doi.org/10.4103/1673-5374.131612

37. Levin MF, Weiss PL, Keshner EA. Emergence of virtual reality as a tool for upper limb rehabilitation: incorporation of motor control and motor learning principles. Phys Ther. 2015;95(3):415-25. https://doi. org/10.2522/ptj.20130579

38. Monteiro-Junior RS, Vaghetti CAO, Nascimento OJM, Laks J, Deslandes AC. Exergames: neuroplastic hypothesis about cognitive improvement and biological effects on physical function of institutionalized older persons. Neural Regen Res. 2016 Mar;11(2):201-4. https://doi.org/10.4103/1673-5374.177709

39. You SH, Jang SH, Kim YH, Hallett M, Ahn SH, Kwon YH, et al. Virtual reality-induced cortical reorganization and associated locomotor recovery in chronic stroke. Stroke. 2005 May;36(6):1166-71. https:// doi.org/10.1161/01.STR.0000162715.43417.91 